\title{
OGG1 DNA Repair Gene Polymorphism As a Biomarker of Oxidative and Genotoxic DNA Damage
}

\author{
Kanika Miglani ${ }^{1}$, Sunil Kumar ${ }^{2}$, Anita Yadav $^{2}$, Neeraj Aggarwal ${ }^{3}$ and Ranjan Gupta ${ }^{{ }^{*}}$ \\ ${ }^{1}$ Department of Biochemistry, Kurukshetra University Kurukshetra, Haryana 136119, \\ India; ${ }^{2}$ Department of Biotechnology, Kurukshetra University Kurukshrtra, Haryana 136119, India; \\ ${ }^{3}$ Department of Microbiology, Kurukshetra University Kurukshetra, Haryana 136119, India
}

Received 4 May 2019; accepted 21 October 2019; published online 31 August 2020

\begin{abstract}
Background: Single nucleotide polymorphisms in OGG1 gene modulates DNA repair capacity and functions as one of the first lines of protective mechanisms against 8-OHdG mutagenicity. OGG1-Cys326 gene polymorphism may decrease DNA repair function, causing oxidative stress due to higher oxidative DNA damage. The main purpose of this study was to examine the link of oxidative and genotoxic DNA damage with DNA repair OGG1 gene polymorphism, in charcoal workers exposed to polyaromatic hydrocarbons. Methods: Urinary 8-OHdG excretion (a biomarker of oxidative DNA damage) was determined in both exposed and control populations. Genotyping of OGG1 DNA repair gene in the blood samples of subjects was carried out by PCR-RFLP method. Results: The 8OHdG urinary concentration was significantly higher $(p<0.05)$ in the exposed (geometric mean $12.33 \pm 3.78$ ) than in the unexposed (geometric mean $7.36 \pm 2.29$ ) population. DNA damage, as measured by $8-\mathrm{OHdG}$ and TM content, was found to be significantly higher in OGG1 homozygous mutants $(\mathrm{mt} / \mathrm{mt} ; 18.81 \pm 3.34 ; 6.04 \pm 0.52)$ as compared to wild-type genotypes (wt/wt; $10.34 \pm 2.25 ; 5.19 \pm 2.50$ ) and heterozygous (wt/mt) mutants (12.82 \pm $2.81 ; 6.04 \pm 0.93$ ) in the exposed group. Conclusion: We found a significant association of OGG1 heterozygous $(w t / m t)$ and homozygous $(\mathrm{mt} / \mathrm{mt})$ variants with oxidative and genotoxic damage, suggesting that these polymorphisms may modulate the effects of PAH exposure in occupational workers. DOI: 10.29252/ibj.25.1.47
\end{abstract}

Keywords: 8-hydroxy-2'-deoxyguanosine, 1-hydroxypyrene, Polycyclic aromatic hydrocarbons

Corresponding Authors: Ranjan Gupta

Department of Biochemistry, Kurukshetra University Kurukshetra, Haryana, 136119, India; Tel. (+91-01744) 238582; Fax: (+91-01744) 238077;

E-mail: r.gupta@kuk.ac.in

\section{INTRODUCTION}

$\mathrm{D}$ uring the process of charcoal production, charcoal workers are continuously exposed to wood smoke and charcoal dust containing fine particulate matters such as PAH and certain gaseous pollutants released from burning wood. Therefore, the concern is charcoal workers who do not use any protective equipment, and there is high probability that they are exposed to PAHs during the charcoal production. PAHs are considered as carcinogenic, mutagenic and immunosuppressive agents due to their interference with the normal functioning of cellular membrane and certain membrane-associated enzymes ${ }^{[1]}$. Exposure to PAHs causes the interaction of this genotoxicant with nuclear DNA, leading to the oxidative and genotoxic DNA damage ${ }^{[2]}$.

An oxidized form of guanosine, $8-\mathrm{OHdG}$, is a biomarker of oxidative DNA damage and is involved in the pathology of many diseases such as cancer, atherosclerosis, and diabetes ${ }^{[3]}$. Base excision DNA repair pathway recognizes $8-\mathrm{OHdG}$ as a threatening lesion, which results in its excretion in human urine without further metabolism ${ }^{[4]}$. Accordingly, estimation of urinary $8-\mathrm{OHdG}$ is increasingly used as a noninvasive biomonitoring approach to assess the oxidative DNA damage produced in the body ${ }^{[5]}$. Comet assay is applied to assess DNA damage/genotoxicity ${ }^{[6]}$. 
Genetic variations in enzyme-encoding genes are involved in xenobiotic metabolism, and DNA repair may influence genotoxicity ${ }^{[7]}$. The combined use of genetic biomarkers and classic epidemiological tools has enabled the identification of the early effects of occupational exposure to distinct pollutant around the world.

Susceptibility to exogenous and endogenous genotoxicants may be modulated by genetic polymorphisms of DNA repair genes. There are multiple DNA repair pathways for repairing various types of DNA damage. These repair pathways involve a number of proteins that play a role in protecting the genome from mutagenic effects. Single nucleotide polymorphisms in DNA repair genes have been identified $^{[8]}$ and shown to contribute to alteration in their DNA repair capacity. Therefore, genetic variations in DNA repair genes have been known to modulate the levels of DNA damage in peripheral blood lymphocytes of the workers exposed to PAH at workplace.

$O G G 1$ is a DNA repair polymorphic gene involved in the base excision repair pathway. Human $O G G l$ is a base excision DNA repair enzyme that participates in the removal of both 8 -oxo-dG and 8 -oxo-G ${ }^{[9,10]}$. Several researchers have already described the association between genetic damage, occupational exposure, and polymorphisms in DNA repair genes, but to the best of our knowledge, it has not been reported in charcoal workers.

\section{MATERIALS AND METHOD}

\section{Subjects}

The study included 77 individuals working in a charcoal-producing kiln from 16 work stations located in Haryana State, India. Charcoal workers were defined as those involved in charcoal production with working hours more than seven hours per day. The control group was comprised of 79 individuals who were not exposed to PAH generated during charcoal production, but the environmental exposure and socioeconomic status of the control population were matched with the exposed group. Control samples were collected from healthy volunteers of the same area of the exposed population but far from the charcoal-producing kilns. All the subjects enrolled in our study were of Asian origin, living in the rural and suburban area of Haryana. A questionnaire was designed to assess the participants' demographic characteristics such as age, consumption habits (smoking, tobacco and drinking habits), and years of work exposure. A person who smoked tobacco through cigarette or bidi (more than 10 cigarettes or bidis) in the routine life was considered as a smoker, while the one who never smoked tobacco throughout his life was regarded as non-smoker. In addition, the person who have consumed alcohol in daily life for the past many years, and the one who have never consumed alcohol throughout his life were considered as alcohol and non-alcohol users, respectively.

\section{Sample collection}

Blood (approximately $5 \mathrm{ml}$ ) and urine samples were collected from charcoal workers exposed to wood smoke and control subjects with the help of a trained technician. All the exposed individuals had minimum of two years of work exposure. Blood and urine samples of the subjects were gathered after the charcoal workers finished their work shift.

\section{Estimation of urinary 1-OHP}

To assess PAH exposure in the exposed population, the level of 1-OHP in the urine samples of exposed and control subjects were analyzed by a former method ${ }^{[11]}$, through GC/MS with minor modifications. To $2 \mathrm{ml}$ of the urine sample, $10 \mu \mathrm{l}$ of $\beta$-glucuronidase/aryl sulfatase was added, and the sample was incubated at $37{ }^{\circ} \mathrm{C}$ for $3 \mathrm{~h}$. The sample was extracted with $5.0 \mathrm{ml}$ of ethyl acetate by mechanical shaking for $20 \mathrm{~min}$. The solution was evaporated in a vacuum rotor to about 0.1 $\mathrm{ml}$. The dry residue was dissolved in $50 \mu \mathrm{l}$ of $\mathrm{N}$ Methyl-N-(trimethylsilyl)trifluoroacetamide, and the tubes were heated at $60{ }^{\circ} \mathrm{C}$ for $30 \mathrm{~min}$. Subsequently, a $1-\mu l$ sample of the solution was injected into the GC system. The gas chromatograph used was an Agilent (U.S.) $7890 \mathrm{~A}$ with a splitless injector. The analytical column was a 30-m HP-5MS column (cross-linked 5\% phenylmethyl silicon, $0.2 \mathrm{~mm}$ of column internal diameter $\times 0.25 \mu \mathrm{m}$ column film thickness. Oven temperature program was set starting at $80{ }^{\circ} \mathrm{C}$, held for $1 \mathrm{~min}$, raised to $320{ }^{\circ} \mathrm{C}$ at $20^{\circ} \mathrm{C} / \mathrm{min}$ and held for 5 min. All mass spectra were obtained with an Agilent 5975 B instrument, and the ion source was operated in the selected ionization mode. Confirmation of the compound was completed by MS characteristic ions, and the ratio of MS characteristic ions and GC retention time was matched with the known standard compound.

\section{Estimation of urinary 8-OHdG}

Urinary $8-\mathrm{OHdG}$ was evaluated with a competitive enzymatic immunoassay kit (Caymen chemical Company, Michigan, USA). The concentration of creatinine was measured spectrophotometerically as described before ${ }^{[12]}$. Level of $8-\mathrm{OHdG}$ was expressed relative to creatinine ( $\mathrm{ng} / \mathrm{mg}$ creatinine). 


\section{Alkaline comet assay}

For genotoxicity assessment, alkaline comet assay was carried out by former methods with minor modifications ${ }^{[13,14]}$. Briefly, dust-free plain slides were covered with a layer of $150 \mu \mathrm{l}$ of $1 \%$ normal melting agarose and dried in a hot air oven for $10 \mathrm{~min}$. The blood samples $(5-10 \mu \mathrm{l})$ were mixed with $90 \mu \mathrm{l}$ of warm $0.5 \%$ low melting agarose (prepared in phosphate buffer saline), and this mixture was layered as the additional second layer and gelled at $4{ }^{\circ} \mathrm{C}$ for 15 min. An additional third layer of $0.5 \%$ low melting agarose was added on top and gelled again at $4{ }^{\circ} \mathrm{C}$ for $15 \mathrm{~min}$. The slides were then put into freshly prepared, chilled lysis buffer solution at $4{ }^{\circ} \mathrm{C}$ for minimum $2 \mathrm{~h}$, followed by incubation in an alkaline electrophoresis buffer for $20 \mathrm{~min}$ and electrophoresis $(25 \mathrm{~V}$ and $300 \mathrm{~mA}$ ) in the same buffer for $30 \mathrm{~min}$. The slides were then immersed in a neutralization buffer (Tris-buffer) and stained with ethidium bromide $(20 \mu \mathrm{g} / \mathrm{ml})$.

\section{Comet scoring}

A total of 50 cells from each of the duplicate slides were examined randomly under a fluorescent microscope. The extent of DNA damage was measured quantitatively as TM value using Lucia Comet Assay software (Version 7.12). The TM was defined as the percentage of DNA in the tail multiplied by the length between the centre of the head and tail ${ }^{[15]}$.

\section{Isolation of genomic DNA}

The genomic DNA was isolated from the whole blood as described elsewhere ${ }^{[16]}$.

\section{OGG1 genotyping}

The presence of the OGG1 Ser326Cys polymorphism was detected by amplifying genomic DNA with the forward (5'-ACTGTCACTAGTCTCAC CAG-3') and the reverse (5'-GGAAGGTGCTTGG GGAAT-3') primers. The 201-bp PCR product was digested with Fnu4H1 at $37{ }^{\circ} \mathrm{C}$ for $1 \mathrm{~h}$. Digested products were separated by electrophoresis and visualized by ethidium bromide staining. Wild-type alleles resulted in a 201-bp fragment, while the variant allele resulted in 100 and 101 base pairs following restriction enzyme digestion.

\section{Statistical analysis}

Mann-Whitney U test was used to compare different variables between the studied groups. The influence of genetic polymorphisms of DNA repair gene and confounding factors on the studied biomarkers among the exposed and control populations was determined by post hoc analysis and Tukey's HSD test using Multivariate analysis of variance. All tests were performed using statistical software system SPSS 16.0. The level of statistical significance was set at $p<0.05$.

\section{Ethical statement}

The above-mentioned sampling protocols were approved by the Human Ethics Committee of Kurukshetra University, Kurukshetra, India (Ethical code: IEC/12/240, 16 may 2012). Written informed consents were provided by all the study subjects.

\section{RESULTS}

\section{Demographic characteristics}

This study was comprised of 77 PAH-exposed charcoal workers and 79 controls, and their demographic characteristics are shown in Table 1. The number of subjects and the mean age in each age group in both control and exposed workers matched demographically. Charcoal workers included in this study had demographically matched mean age of 34.83 \pm 11.05 , which ranged from 17 to 57 years old. Regarding consumption habits, i.e. smoking, alcohol consumption, and tobacco chewing, the distribution was found to be non-significant between the charcoal workers and control subjects. The charcoal workers under study were occupationally exposed to wood smoke for an average time of $7.99 \pm 4.54$ years.

\section{Estimation of urinary 1-OHP}

In our study, the mean concentrations of urinary 1OHP levels in both control and exposed subjects were found to be $25.59 \pm 16.55 \mathrm{ng} / \mathrm{mg}$ creatinine and $161.59 \pm 58.77 \mathrm{ng} / \mathrm{mg}$ creatinine, respectively. The chromatogram depiction of this result has been reported in one of our published research article ${ }^{[17]}$.

\section{Estimation of urinary 8-OHdG}

The $8-\mathrm{OHdG}$ urinary concentration, a marker of oxidative DNA damage, was significantly higher $(p<$ 0.05 ) in the exposed (geometric mean $12.33 \pm 3.78$; 6.33-24.25) than in the unexposed (geometric mean $7.36 \pm 2.29$; 3.46-15.20) populations (Table 2).

\section{Association between oxidative stress repair gene and DNA damage}

The effects of genetic polymorphism of $O G G 1$ gene on 8-OHdG content in both exposed and non-exposed population were investigated. Genetic variants of $O G G 1$ in all the subjects were analyzed by PCR-RFLP.

The subjects with the mutant $O G G 1$ Ser326Cys genotype had significantly higher oxidative DNA 
Table 1. Demographic characteristics of the control and exposed groups

\begin{tabular}{|c|c|c|c|c|c|c|c|c|}
\hline \multirow[t]{2}{*}{ Variables } & \multicolumn{2}{|c|}{$\begin{array}{l}\text { Control } \\
(n=79)\end{array}$} & \multicolumn{2}{|c|}{$\begin{array}{c}\text { Charcoal workers } \\
(n=77)\end{array}$} & \multicolumn{2}{|c|}{$95 \% \mathrm{CI}$} & \multirow{2}{*}{$\begin{array}{c}p \\
\text { value }\end{array}$} & \multirow{2}{*}{ OR } \\
\hline & $\mathbf{N}(\%)$ & Mean \pm SD & $\mathbf{N}(\%)$ & Mean \pm SD & Lower & Upper & & \\
\hline \multicolumn{9}{|l|}{ Age (y) } \\
\hline $10-20$ & $5(6.32)$ & $18.8 \pm 0.84$ & 7 (9.09) & $17.7 \pm 1.25$ & & & & \\
\hline $21-30$ & $21(26.5)$ & $25.57 \pm 2.75$ & $23(29.8)$ & $25.2 \pm 2.84$ & & & & \\
\hline $31-40$ & $27(34.1)$ & $32.63 \pm 2.51$ & $24(31.6)$ & $36.3 \pm 2.61$ & & & & \\
\hline $41-50$ & $18(22.7)$ & $45.22 \pm 2.92$ & $16(20.7)$ & $45.5 \pm 3.39$ & & & & \\
\hline $51-60$ & $8(3.41)$ & $54.38 \pm 2.39$ & 7 (9.09) & $54.3 \pm 3.20$ & & & & \\
\hline Smoking & & & & & 0.44 & 1.60 & 0.99 & 0.84 \\
\hline Smoker & $46(58.2)$ & & $48(62.3)$ & & & & & \\
\hline Non-smoker & $33(41.7)$ & & $29(37.7)$ & & & & & \\
\hline Alcohol intake & & & & & 0.73 & 2.56 & 0.172 & 1.35 \\
\hline Alcoholic & $41(51.9)$ & & $34(44.2)$ & & & & & \\
\hline Non-alcoholic & $38(48.1)$ & & $43(55.8)$ & & & & & \\
\hline Tobacco chewing & & & & & 0.59 & 5.80 & 0.590 & 1.85 \\
\hline Tobacco chewer & $9(11.4)$ & & $5(6.49)$ & & & & & \\
\hline Non-tobacco chewer & $70(88.6)$ & & $72(93.5)$ & & & & & \\
\hline Work exposure (y) & & & & $7.99 \pm 4.54$ & & & & \\
\hline$<10$ & & & $50(64.9)$ & $5.25 \pm 2.24$ & & & & \\
\hline $10-20$ & & & $25(32.7)$ & $12.40 \pm 1.96$ & & & & \\
\hline$>20$ & & & $2(2.60)$ & $21.50 \pm 0.71$ & & & & \\
\hline
\end{tabular}

Student's- $t$ test was applied to compare the mean value of age between the control and exposed populations. Chi-square test was applied to test differences in age, consumption habits, and work exposure experience.

damage as measured by urinary 8 -OHdG levels, compared to the wild type of $O G G 1$ Ser326Ser genotype in exposed as well as non-exposed population $(p<0.05)$. The values of $8-\mathrm{OHdG}$ were significantly higher in the exposed population compared to the controls (Table 2). The result for the effect of $O G G 1$ polymorphism on TM content has been summarized in Table 3. The 8-OHdG and TM content were significantly higher in Cys/Cys OGG1 genotypes $(\mathrm{mt} / \mathrm{mt} ; 18.81 \pm 3.34 ; 6.04 \pm 0.52)$ as compared to Ser/Cys (wt/mt 12.82 $\pm 2.81 ; 5.40 \pm 0.84)$ and Ser/Ser genotypes (wt/wt; $10.34 \pm 2.25 ; 5.19 \pm 0.78)$ in charcoal workers. The levels of both oxidative and genotoxic damage were significantly higher in charcoal workers than in the control population. Results of linear regression analysis adjusted for demographic characteristics such as age, consumption habits, and exposure duration are shown in Table 4.

\section{DISCUSSION}

Exposure to PAH in charcoal workers can be due to inhalation or by dermal contact. PAH is known to exert toxic effects even at relatively low concentrations. Such toxicity could be modulated by mutant genotypes of DNA repair gene, causing an increase in the susceptibility to various diseases ${ }^{[18]}$. Thus, the main goal of our study was to assess the modulatory effect of gene polymorphism of DNA repair gene on oxidative DNA damage in charcoal workers. These workers had the higher levels of urinary 1-OHP as compared to reference values, indicating high exposure to $\mathrm{PAH}$. Urinary 1-OHP levels in occupational workers were higher than those of control population as suggested by Wenjuan et $a{ }^{[19]}$. These observations are also in accordance with those reported previously by $\mathrm{Fu}$ et al. ${ }^{[20]}$ and

Table 2. Levels of urinary 8-OHdG in the control and exposed populations

\begin{tabular}{lcccccc}
\hline Biomarker of effect & \multirow{2}{*}{ Group } & Mean \pm SD & \multirow{2}{*}{ Minimum } & \multirow{2}{*}{ Maximum } & \multicolumn{2}{c}{ 95\% CI for mean } \\
\cline { 5 - 7 } & Urinary 8-OHdG & Control & $7.36 \pm 2.29$ & 3.46 & 15.20 & 6.85 \\
(ng/mg creatinine) & Exposed & $12.33 \pm 3.78^{*}$ & 6.33 & 24.25 & 11.47 & Upper \\
\hline
\end{tabular}

Mann-Whitney U test was applied to compare the mean values between the control and exposed groups. "Significant at $p<0.05$ 
Table 3. Effect of $O G G 1$ genotype on urinary $8-\mathrm{OHdG}$ content (ng/mg creatinine) and TM $(\mu \mathrm{m})$

\begin{tabular}{|c|c|c|c|c|c|c|}
\hline \multirow[b]{2}{*}{ Genotype } & \multicolumn{3}{|c|}{ Control population $(n=79)$} & \multicolumn{3}{|c|}{ Charcoal workers $(n=77)$} \\
\hline & $\mathbf{N}$ & $\begin{array}{c}\text { Urinary 8-OHdG } \\
\text { content }(\text { mean } \pm \text { SD) }\end{array}$ & $\begin{array}{c}\text { TM content } \\
(\text { mean } \pm \text { SD })\end{array}$ & $\mathbf{N}$ & $\begin{array}{c}\text { Urinary } 8-\mathrm{OHdG} \\
\text { content }(\text { mean } \pm \mathrm{SD})\end{array}$ & $\begin{array}{l}\text { TM content } \\
(\text { mean } \pm \text { SD) }\end{array}$ \\
\hline wt/wt & 50 & $8.15 \pm 2.50$ & $1.40 \pm 0.33$ & 39 & $10.34 \pm 2.25$ & $5.19 \pm 0.78$ \\
\hline $\mathbf{w t} / \mathbf{m t}$ & 25 & $6.04 \pm 0.93^{*}$ & $1.33 \pm 0.32$ & 28 & $12.82 \pm 2.81$ & $5.40 \pm 0.84$ \\
\hline $\mathbf{m t} / \mathbf{m t}$ & 4 & $5.67 \pm 0.62^{*}$ & $1.01 \pm 0.07^{*}$ & 10 & $18.81 \pm 3.34^{*}$ & $6.04 \pm 0.52^{*}$ \\
\hline
\end{tabular}

Multivariate analysis of covariance test was used to test the differences in the urinary 8-OHdG content; TM was adjusted for age, consumption habits, and exposure duration among the control and exposed groups. " Significant at $p<0.05$

Nguyen et $_{\text {al. }}{ }^{[21]}$ who described the toxicity of PAH as a consequence of imbalance between pro-oxidant and antioxidant homeostasis, the so called oxidative stress, which ultimately leads to oxidative damage. Therefore, to assess the differential impact of such toxicants on the exposed individuals, we investigated the association of genetic polymorphism of $O G G 1$ gene with oxidative and genotoxic damage biomarkers in the exposed and control groups. Our study found that OGG1 polymorphisms are significantly related to oxidative and genotoxic damage, and mutant type genotype presented higher levels of DNA damage. These results are similar to findings of Chen et al. ${ }^{[22]}$ who showed higher repair activity of $O G G 1 \mathrm{Ser} / \mathrm{Ser}$ for 8-OHdG than the OGG1 Cys/Cys. Also, Aka et al. ${ }^{[23]}$ and Pawlowska et al. ${ }^{[24]}$ observed that Cys/Cys and Ser/Cys $O G G 1$ genotypes had less DNA repair capacity compared to the Ser/Ser OGGI genotype.

There are a number of clinical studies in agreement with our results, indicating that the mutant genotypes of $O G G 1$ have higher DNA damage and lower repair capacity of 8 -OHdG than wild-type genotype ${ }^{[25,26]}$, which is associated with the risk of lung cancer ${ }^{[26]}$, type 2 diabetes ${ }^{[27]}$, breast cancer $^{[28]}$ and nasopharyngeal carcinoma ${ }^{[29]}$. Some previous researchers have deduced that the reduced DNA repair capacity of mutant $O G G 1$ genotypes may result from either the loss of a putative regulatory serine phosphorylation site or the introduction of a redox-sensitive cysteine amino acid at position $326^{[30]}$. The process of recognition and repair of 8-oxoguanine by $O G G 1$ is well understood and reviewed ${ }^{[10]}$, and it represents one of the oldest DNA base excision repair pathways, which constitutes a major area in studies of DNA repair mechanisms and led to the 2015 Nobel Prize in Chemistry.

Charcoal workers with mutant $O G G 1$ genotypes have higher urinary $8-\mathrm{OHdG}$ content and $\mathrm{TM}$ as compared with wild-type genotypes. These results imply that charcoal workers with mutant OGG1 genotypes are more susceptible to oxidative and genotoxic DNA damage. Since oxidative and genotoxic damage are important considerations in events leading to cancer after carcinogenic/ genotoxicant exposure, precautions should be taken by occupational workers to minimize direct exposure to PAH arising from the incomplete combustion of wood. Accordingly, there is a need to inform these workers about the potential hazards of occupational exposure and should always be provided with appropriate personal protective equipment.

The outcomes of the present study show that there is a significant association of $O G G 1$ heterozygous $(\mathrm{wt} / \mathrm{mt})$ and homozygous $(\mathrm{mt} / \mathrm{mt})$ variants with the oxidative and genetic damage as assessed by $8-\mathrm{OHdG}$ level and TM content, respectively in the studied population. These findings suggest that charcoal workers with mutant $O G G 1$ genotypes are more susceptible to the oxidative and genotoxic DNA damage. However, further studies should be conducted on the DNA repair gene expression and DNA repair capacity with a large sample size.

Table 4. Association of $O G G 1$ genotype with the urinary $8-\mathrm{OHdG}$ content (ng/mg creatinine) and TM $(\mu \mathrm{m})$

\begin{tabular}{lccccccc}
\hline \multirow{2}{*}{ OGG1 polymorphism } & \multicolumn{3}{c}{ Urinary 8-OHdG } & & \multicolumn{3}{c}{ TM $(\boldsymbol{\mu m})$} \\
\cline { 2 - 4 } \cline { 6 - 8 } & $\boldsymbol{\beta}^{\mathbf{a}}$ & $\mathbf{R}^{\mathbf{2}}$ & $\boldsymbol{p}^{\mathbf{b}}$ value & & $\boldsymbol{\beta}^{\mathbf{a}}$ & $\mathbf{R}^{\mathbf{2}}$ & $\boldsymbol{p}^{\mathbf{b}}$ value \\
\hline Control group $(\mathrm{n}=79)$ & 0.073 & 0.236 & $0.025^{*}$ & & 0.022 & 0.149 & $0.000^{*}$ \\
Exposed group $(\mathrm{n}=77)$ & -0.162 & 0.603 & $0.000^{*}$ & & -0.168 & 0.576 & $0.000^{*}$ \\
\hline
\end{tabular}

Regression analysis was used to test differences in the urinary 8-OHdG content and TM adjusted for age, consumption habits, and exposure duration. ${ }^{*}$ values are significant. ${ }^{\mathrm{a}}$ Unstandardized coefficient; ${ }^{\mathrm{b}}$ model $p$ value 


\section{ACKNOWLEDGEMENTS}

We are thankful to the University Grants Commission, New Delhi, India for funding through Sanction Letter no. F. No. 42-646/2013 (SR) and to all the blood donors for their voluntary participation in our study.

CONFLICT OF INTEREST. None declared.

\section{REFERENCES}

1. Rajendran P, Jayakumar T, Nishigaki I, Ekambaram G, Nishigaki Y, Vetriselvi J, Sakthisekaran S. Immunomodulatory effect of mangiferin in experimental animals with benzo(a) pyrene-induced lung carcinogenesis. International journal of biomedical science 2013; 9(2): 68-74.

2. Nita M, Grzybowski A. The role of the reactive oxygen species and oxidative stress in the patho mechanism of the age-related ocular diseases and other pathologies of the anterior and posterior eye segments in adults. Oxidative medicine and cellular longevity 2016; 3164734.

3. Gao Y, Wang P, Wang Z, Han L, Li J, Tian C, Zhao F, Wang J, Zhao F, Zhang Q and Yumin Lyu Y. Serum 8Hydroxy-2'-deoxyguanosine level as a potential biomarker of oxidative DNA damage induced by ionizing radiation in human peripheral blood. Dose response 2019; 17(1): doi: 10.1177/1559325818820649.

4. Maynard S, Schurman SH, Harboe C, de Souza-Pinto NC, Bohr VA. Base excision repair of oxidative DNA damage and association with cancer and aging. Carcinogenesis 2009; 30(1): 2-10.

5. Pawlas N, Olewińska E, Markiewicz-Górka I, Kozłowska A, Januszewska L, Lundh T, Januszewska E, Pawlas K. Oxidative damage of DNA in subjects occupationally exposed to lead. Advances in clinical and experimental medicine 2017; 26(6): 939-945.

6. Pandey AK, Bajpayee M, Parmar D, Rastogi SK, Mathur N, Seth PK, Dhawan A. DNA damage in lymphocytes of rural Indian women exposed to biomass fuel smoke as assessed by the comet assay, Environmental and molecular mutagenesis 2005; 45(5): 435-441.

7. Wong RH, Chang SY, Ho SW, Huang PL, Liu YJ, Chen $\mathrm{YC}$, Yeh YH, Lee HS. Polymorphisms in metabolic GSTP1 and DNA-repair XRCC1 genes with an increased risk of DNA damage in pesticide-exposed fruit growers. Mutation research 2008; 654(2): 168-175.

8. Christmann M, Tomicic MT, Roos WP, Kaina B. Mechanisms of human DNA repair: an update. Toxicology 2003; 193(1-2): 3-34.

9. Ba X, Aguilera-Aguirre L, Ain Nmi Rashid QT, Bacsi A, Radak Z, Sur S, Hosoki K, Hegde ML, Boldogh I. The role of 8-oxoguanine DNA glycosylase-1 in inflammation. International journal of molecular science 2014; 15(9): 16975-16997.
10. Karihtala P, Kauppila S, Puistola U, Jukkola-Vuorinen A. Absence of the DNA repair enzyme human 8oxoguanine glycosylase is associated with an aggressive breast cancer phenotype. British journal of cancer 2012; 106(2): 344-347.

11. Shin HS, Lim HH. Simultaneous determination of 2naphthol and 1-hydroxy pyrene in urine by gas chromatography-mass spectrometry. Journal of chromatography B 2011; 879(7-8): 489-494.

12. Jaffe M. Ueber den Niederschlag welchen Pikrinsäure in normalen Harn erzeugt und über eine neue reaction des Kreatinins. Hoppe-seyler's zeitschrift fur physiologische chemie 1886; 10: 391-400.

13. Singh NP, McCoy MT, Tice RR, Schneider EL. A simple technique for quantitation of low levels of DNA damage in individual cells. Experimental cell research 1988; 175(1): 184-191.

14. Tice RR, Agurell E, Anderson D, Burlinson B, Hartmann A, Kobayashi H, Miyamae Y, Rojas E, Ryu JC, Sasaki YF. Single cell gel/comet assay: guidelines for in vitro and in vivo genetic toxicology testing. Environmental and molecular mutagenesis 2000; 35(3): 206-221.

15. Olive PL, Banath JP, Durand RE. Heterogeneity in radiation-induced DNA damage and repair in tumor and normal cells measured using the "comet" assay. Radiation research 1990; 122(1): 86-94.

16. Miller SA, Dykes DD, Polesky HF. A simple salting out procedure for extracting DNA from human nucleated cells. Nucleic acids research 1988; 16(3): 1215.

17. Miglani K, Ahmad I, Yadav A, Aggarwal N, Gupta R. Evaluation of oxidative damage and antioxidant defense potential in charcoal workers exposed to polyaromatic hydrocarbons. International journal of current research 2016; 8: 35454-35463.

18. Choosong T, Phakthongsuk P, Tekasakul S, Tekasakul, P. Urinary 1-hydroxypyrene levels in workers exposed to polycyclic aromatic hydrocarbon from rubber wood burning. Safety and health at work 2014; 5(2): 86-90.

19. Wenjuan C, Jianzhong L, Chong L, Yanjun G, Keqing L, Hanzhang W, Zhiping W. The hOGG1 Ser326Cys gene polymorphism and susceptibility for bladder cancer: A meta-analysis. International Brazilian journal of urology 2016; 42(5): 883-896.

20. Fu Y, Niu Y, Pam B, Liu Y, Zhang B, Li X, Yang A, Nie J, Wang R, Yang J. OGG1 methylation mediated the effects of cell cycle and oxidative DNA damage related to PAHs exposure in Chinese coke oven worker. Chemosphere 2019; 224:48-57.

21. Nguyen TTU, Kawanami S, Kawai K, Kasai H, Li YS, Inoue J, Ngoan LT, Horie S. Urinary 1-hydroxypyrene and 8-hydroxydeoxyguanosine levels among coke-oven workers for 2 consecutive days. Journal of occupational health 2014; 56(3): 178-185

22. Chen SK, Hsieh WA, Tsai MH, Chen CC, Hong AI, Wei YH, Chang WP. Age-associated decrease of oxidative repair enzymes, human 8-oxoguanine DNA glycosylases (hOGG1), in human aging. Journal of radiation research (Tokyo) 2003; 44: 31-35.

23. Aka P, Mateuca R, Buchet JP, Thierens H, Kirsch- 
Volders M. Are genetic polymorphisms in OGG1, $X R C C 1$ and $X R C C 3$ genes predictive for the DNA strand break repair phenotype and genotoxicity in workers exposed to low dose ionising radiations? Mutation research 2004; 556(1-2): 169-181.

24. Pawlowska E, Janik-Papis K, Rydzanicz M, Zuk K, Kaczmarczyk D, Olszewski J, Szyfter K, Blasiak J, Morawiec-Sztandera A. The Cys326 allele of the 8oxoguanine DNA N-glycosylase 1 gene as a risk factor in smoking- and drinking-associated larynx cancer. Tohoku journal of experimental medicine 2009; 219(4): 269-275.

25. Paz-Elizur T, Krupsky M., Blumenstein S, Elinger D, Schechtman E, Zvi Livneh Z. DNA repair activity for oxidative damage and risk of lung cancer. Journal of the national cancer institute 2003; 95(17): 1312-1319.

26. Wei Q, Cheng L, Hong WK, Spitz MR. Reduced DNA repair capacity in lung cancer patients. Cancer research 1996; 56(18): 4103-4107.

27. Chen H, Sun C, Guo W, Meng R, Du H, Qi Q, Gu X, Li
L, Zhang K, Zhu D, Wang Y. AluYb8 insertion in the MUTYH gene is related to increased $8-\mathrm{OHdG}$ in genomic DNA and could be a risk factor for type 2 diabetes in a Chinese population. Molecular and cellular endocrinology 2011; 332(1-2): 301-305.

28. Synowiec E, Stefanska, J, Morawiec, Z, Blasiak J, Wozniak K. Association between DNA damage, DNA repair genes variability and clinical characteristics in breast cancer patients. Mutation research 2008; 648(12): 65-72.

29. Cho EY, Hildesheim A, Chen CJ, Hsu MM, Chen IH, Mittl BF, Levine PH, Liu MY, Chen JY, Brinton LA, Cheng YJ, Yang CS. Nasopharyngeal carcinoma and genetic polymorphisms of DNA repair enzymes XRCC1 and hOGG1. Cancer epidemiology biomarker and prevention 2003; 12(10): 1100-1104.

30. Smart DJ, Chipman JK, Hodges NJ. Activity of OGG1 variants in the repair of pro-oxidant-induced 8-oxo-2'deoxyguanosine. DNA repair 2006; 5(11): 1337-1345. 